\title{
Reduksi Logam Berat Cd(II) dan Cr(IV) Pada Sistem Kontinyu Menggunakan Phanerochaete chrysosporium Yang Diradiasi Sinar Gamma
}

\section{Heavy Metal Reduction of Cd (II) and Cr (IV) In Continuous System Using Gamma Rays Irradiated Phanerochaete chrysosporium}

\author{
TRI RETNO D.L. ${ }^{1)}$,NANA MULYANA. ${ }^{1)}$ NURMAYA A.2) DAN SISKA P.S.2) \\ 1) Pusat Aplikasi Isotop dan Radiasi, Badan Tenaga Nuklir Nasional, Jakarta 12440. \\ ${ }^{2)}$ Fakultas Sains dan Teknologi, Universitas Islam Negeri Syarif Hidayatullah, Jakarta 12240. \\ E-mail : tretno@batan.go.id
}

\begin{abstract}
Heavy metal wastes of $\mathrm{Cd}$ (II) and Cr (IV) that are toxic dissolved into surface waters will increase the amount of metal ions in the water. Fungi biomass capable of absorbing heavy metal ions in significant quantities. The mechanism of heavy metals reduction using biosorption. Reduction of metal ions with continuous system will be more efficient for their continuous contact between the adsorbent and the solution. The treatment of low-dose gamma radiation in fungi Phanerochaete chrysosporium ( $P$. chrysosporium) stimulates increased activity of the enzyme so that the resistance of fungi to heavy metal ions increases and metal bonding to be great. Fungi $P$. chrysosporium irradiated with gamma ray doses: 0, 250, 500, 750 and 1000 Gy. The process parameters were observed $\mathrm{pH}$ and fungal viability. Biosorption Metal Cd (II) and Cr (IV) in a continuous system consisting of: FO (without P. chrysosporium), $F 1$ ( $P$. chrysosporium $0 \mathrm{~Gy}$ ) and F2 ( $P$. chrysosporium $750 \mathrm{~Gy}$ ) with a retention time $T 1=3$ hours, $T 2=6$ hours, 9 hours and T3 $=T 4=12$ hours as well as the flow rate of $R 1=32 \mathrm{ml} /$ hour, $R 2=58 \mathrm{ml} /$ hour and $R 3=204 \mathrm{ml} /$ hour. Biosorption using the initial solution, each containing $50 \mathrm{ppm}$ metal $\mathrm{Cd}$ (II) and $\mathrm{Cr}$ (IV) with a pH of 5.5. The results obtained showed that the metal biosorption of Cd (II) and Cr (IV) in a continuous system at treatment R3F2 optimal retention time $T 4=12$ hours namely, providing Cd uptake of $5.96 \mathrm{mg} / \mathrm{g}$ and $\mathrm{Cr}$ uptake of $1.07 \mathrm{mg} / \mathrm{g}$.
\end{abstract}

Keywords: Phanerochaete chrysosporium, gamma irradiation, cadmium, chromium, continuous system

\section{ABSTRAK}

Limbah logam berat $\mathrm{Cd}(\mathrm{II})$ dan $\mathrm{Cr}$ (IV) terlarut bersifat toksid dalam perairan akan meningkatkan jumlah ion logam di dalam air. Biomassa fungi mampu menyerap ion logam berat dalam jumlah signifikan. Mekanisme reduksi logam berat secara biosorpsi. Reduksi ion logam dengan sistem kontinyu lebih efisien karena adanya kontak kontinyu antara adsorben dan larutan. Perlakuan radiasi sinar gamma dosis rendah pada fungi Phanerochaete chrysosporium ( $P$. chrysosporium ) menstimulasi peningkatan aktivitas enzim sehingga ketahanan fungi terhadap ion logam berat meningkat dan pengikatan logam menjadi besar. Fungi $P$. chrysosporium diradiasi sinar gamma dengan dosis :0, 250, 500, 750 dan 1000 Gy. Parameter proses yang diamati meliputi $\mathrm{pH}$ dan viabilitas fungi. Biosorpsi Logam $\mathrm{Cd}$ (II) dan $\mathrm{Cr}$ (IV) di dalam sistem kontinyu terdiri dari: F0 (tanpa $P$. chrysosporium), F1 ( $P$. chrysosporium 0 Gy) dan F2 ( $P$. chrysosporium $750 \mathrm{~Gy}$ ) dengan waktu retensi $\mathrm{T} 1=3 \mathrm{jam}, \mathrm{T} 2=6 \mathrm{jam}, \mathrm{T} 3=9$ jam dan $\mathrm{T} 4=12$ jam serta laju alir R1 = $32 \mathrm{ml} / \mathrm{jam}, \mathrm{R} 2=58 \mathrm{ml} / \mathrm{jam}$ dan R3 $=204 \mathrm{ml} / \mathrm{jam}$. Biosorpsi menggunakan larutan awal mengandung masing-masing $50 \mathrm{ppm}$ logam $\mathrm{Cd}(\mathrm{II})$ dan $\mathrm{Cr}(\mathrm{IV})$ dengan $\mathrm{pH}$ 5,5. Hasil yang diperoleh menunjukkan bahwa biosorpsi logam $\mathrm{Cd}(\mathrm{II})$ dan $\mathrm{Cr}(\mathrm{IV})$ dalam sistem kontinyu optimal pada perlakuan R3F2 dengan waktu retensi T4 = 12 jam yakni, memberikan serapan $\mathrm{Cd}$ sebesar 5,96 $\mathrm{mg} / \mathrm{g}$ dan serapan Cr sebesar $1,07 \mathrm{mg} / \mathrm{g}$.

Kata kunci: Phanerochaete chrysosporium, radiasi gamma, kadmium, kromium,sistem kontinyu 


\section{PENDAHULUAN}

\subsection{Latar Belakang}

Logam Cd dan kromium ( $\mathrm{Cr}$ ), berasal dari industri pelapisan logam, metalurgi, plastik, industri cat, petrokimia, baterai, kertas, dan pulp. Ini merupakan logam berat yang berbahaya bagi lingkungan ${ }^{(1)}$. Industri pelapisan krom menghasilkan limbah dengan konsentrasi ratarata $75.900 \mathrm{mg} / \mathrm{L}$ dalam bentuk $\mathrm{CrO}_{4}{ }^{2-(2)}$. Menurut Peraturan Pemerintah Nomor 82 Tahun 2001, nilai ambang batas limbah krom heksa-valensi $\mathrm{Cr}$ (VI) adalah $1 \mathrm{mg} / \mathrm{L}$. Limbah buangan $\mathrm{Cd}$ di kawasan industri pelapisan logam mencapai 0,5 $\mathrm{mg} / \mathrm{L}$ dan telah melebihi baku mutu limbah cair Cd yaitu $0,01 \mathrm{mg} / \mathrm{L}^{(3)}$

Pengolahan limbah logam berat secara fisika dan kimia menimbulkan limbah sekunder dan mahal( ${ }^{(4)}$. Pengolahan limbah secara biologi yang menggunakan mikroorganisme sebagai biosorben untuk menyerap logam berat, merupakan teknologi alternatif yang berpotensi untuk dikembangkan. Keuntungan dari pemanfaatan mikroorganisme adalah ramah lingkungan, murah, daya ikat logam tinggi, memiliki mekanisme desorpsi recovery logam, dan dapat dimanfaatkan kembali ${ }^{(5)}$.

Fungi white rot, dengan spesifikasi substrat yang sangat rendah, memineralisasi polutan organik rekalsitran dengan struktur mirip lignin ${ }^{(6)}$. $P$. chrysosporium memiliki kemampuan menyerap ion logam secara signifikan dan menghasilkan enzim lignin peroksidase (LiP), mangan peroksidase $(\mathrm{MnP})$, dan laktase. Enzim tersebut mampu mengakses non polar dan non- soluble senyawa toksik ${ }^{(7)}$. $P$. chrysosporium mampu mengakumulasi ion $\mathrm{Cr}(\mathrm{VI})$ dengan gugus fungsional aktif pada permukaan sel dan dapat mengadsorpsi ion $\mathrm{Cr}(\mathrm{VI})$ mencapai $78,5 \%{ }^{(8)}$.

Perlakuan sinar gamma pada fungi menstimulasi aktivitas enzim sehingga ketahanan daya terhadap ion meningkat dan pengikatan logam menjadi besar ${ }^{(9,10)}$. Hal ini menyebabkan terjadinya stress oksidatif sel, sehingga sel akan mengembangkan mekanisme proteksi diri untuk melawan efek oksigen reaktif dengan menghasilkan enzim ekstraseluler yang lebih banyak ${ }^{(11)}$. Pengaruh sinar gamma dosis rendah pada $P$. chrysosporium memberikan serapan tertinggi $\mathrm{Pb}(\mathrm{II})$ sebesar $14,92 \mathrm{mg} / \mathrm{g}$ dan $\mathrm{Cd}(\mathrm{II})$ sebesar $1,17 \mathrm{mg} / \mathrm{g}^{(12)}$.

Reduksi logam berat dilakukan dalam reaktor biosorpsi logam berat $\mathrm{Pb}$ dengan fungi Aspergillus niger yang menggunakan sistem kontinu pada larutan limbah cair memberikan efisiensi reduksi logam $\mathrm{Pb}$ sebesar $96,12 \%{ }^{(13)}$. Hal ini menunjukan sistem kontinu lebih efisien dalam mengadsorpsi logam berat karena terjadi kontak kontinu antara adsorben dengan larutan segar $^{(14)}$.

\subsection{Tujuan}

Penelitian ini bertujuan mengevaluasi kemampuan radiasi $P$. chrysosporium sebagai biosorben $\mathrm{Cd}(\mathrm{II})$ dan $\mathrm{Cr}(\mathrm{VI})$ di dalam sistem kontinu dengan variasi waktu retensi. Parameter yang digunakan adalah pengamatan $\mathrm{pH}$, viabilitas fungi, kadar ion $\mathrm{Cd}(\mathrm{II})$ dan ion $\mathrm{Cr}(\mathrm{VI})$ menggunakan Atomic Absorption Spectrophotometer (AAS).

\section{BAHAN DAN METODE}

Alat yang digunakan adalah $\mathrm{pH}$ meter, oven (Memmert), shaker mekanis, autoklaf (Wise), magnetic stirrer, petri dish, inkubator (Heracus), neraca analitik (Acculab), cawan masir, bunsen, irradiator gamma chamber 4000A dengan laju dosis 2,1 KGy/jam, hand sprayer, laminar air flow (Panasonic), desikator (Sanplatec), AAS ( Atomic Absorption Spectrophotometer Perkin - Elmer), dan peralatan gelas lainnya.

Bahan yang digunakan adalah kultur fungi $P$. chrysosporium, Potato Dextrose Agar (PDA), Potato Dextrose Broth (PDB), Carboxymethyl Cellulose (CMC), $\mathrm{K}_{2} \mathrm{Cr}_{2} \mathrm{O}_{7}, \mathrm{Cd}_{2} \mathrm{SO}_{4}$.

\subsection{Inkubasi kultur fungi P.chrysosporium ${ }^{(15)}$}

Kultur fungi $P$. chrysosporium dipapari sinar gamma 0 (kontrol), 250 Gy, 500 Gy, 750 Gy, dan 1000 Gy dalam media PDB diinkubasi dan diaduk dengan shaker pada kecepatan100 rpm selama 4 hari. Kultur fungi $100 \mu$ l dinkubasi pada media PDA pada suhu $30^{\circ} \mathrm{C}$ selama 4-6 hari.

\subsection{Orientasi dosis iradiasi Gamma ${ }^{(12)}$}

Kemampuan tumbuh $P$. chrysosporium hasil radiasi dievaluasi dengan menambahkan larutan logam $\mathrm{Cd}$ (II) 50 ppm dan larutan $\mathrm{Cr}(\mathrm{VI}) 50$ ppm. Medium cair sebanyak $30-40 \mathrm{~mL}$ dalam 12 gelas ukur $250 \mathrm{~mL}$ disterilkan dengan autoclave pada suhu $121^{\circ} \mathrm{C}$ selama 15 menit. Kultur fungi $P$. chrysosporium ukuran $0,5 \times 0,5 \mathrm{~cm}$ dalam medium cair tersebut diinkubasi dengan shake 100 rpm selama 3-4 hari. Supernatan dan biomassa mikroba disentrifuse $12000 \mathrm{rpm}$ selama 15 menit. Biomassa mikroba pada cawan porselen dikeringkan dalam oven $60^{\circ} \mathrm{C}$ selama 48-72 jam. Variabel pengamatan terdiri dari $\mathrm{pH}$ supernatan dan bobot kering biomassa mikroba.

\subsection{Pembuatan Bahan Pembawa(16)}

Bahan pembawa (carrier) terdiri dari $500 \mathrm{~g}$ CMC, $100 \mathrm{~g}$ kompos, $250 \mathrm{~g}$ bubuk talk dan 50 $\mathrm{mL}$ aquades dicampur rata sehingga membentuk granula, kemudian dikeringkan di dalam oven pada suhu $60^{\circ} \mathrm{C}$. 


\subsection{Pembuatan inokulan P. chrysosporium}

$P$. chrysosporium radiasi dosis optimum $X$ Gy (F2) dan P.chrysosporium radiasi 0 Gy (F1) dalam $25 \mathrm{~mL}$ media cair PDB dengan viabilitas awal $10^{7} \mathrm{spora} / \mathrm{ml}$ diinkubasi pada shaker 100 rpm selama 4 hari. Carrier organik padat seberat $40 \mathrm{~g}$ dalam kantong plastik (polyethylene) disterilkan dengan radiasi sinar gamma 25 kGy, kemudian kultur cair fungi F1 dan F2 diinokulasi dan diinkubasi pada suhu $28-30^{\circ} \mathrm{C}$ selama 14 hari. Carrier tanpa fungi (F0) digunakan sebagai kontrol. Variabel pengamatan terdiri dari $\mathrm{pH}$, kadar air, bahan organik, abu dan viabilitas fungi.

\subsection{Penentuan efisiensi serapan $\mathrm{Cd}$ dan $\mathrm{Cr}$ dalam medium cair}

Efisiensi serapan fungi IFO (inokulan tanpa $P$. chrysosporium), IF1 (inokulan $P$. chrysosporium 0 Gy), dan IF2 (inokulan $P$. chrysosporium $\mathrm{X}$ Gy) dievaluasi melalui penambahan larutan logam $\mathrm{Cd}(\mathrm{II}) 50 \mathrm{ppm}$ dan larutan logam $\mathrm{Cr}(\mathrm{VI}) 50 \mathrm{ppm}$ dalam medium PDB. Medium cair $40 \mathrm{~mL}$ dalam botol $250 \mathrm{~mL}$ ini disterilkan dengan autoclave pada $121^{\circ} \mathrm{C}$ selama 15 menit, kemudian ditambahkan inokulan fungi (IF0, IF1, IF2) sebesar $2 \mathrm{gr}$ dan diinkubasi dalam shaker pada $100 \mathrm{rpm}$ dan suhu $28-32^{\circ} \mathrm{C}$ selama 3 hari. Supernatan dan endapan disentrifuse pada 12000 rpm selama 15 menit agar terpisah. Variabel pengamatan terdiri dari $\mathrm{pH}$ supernatan dan efisiensi serapan $\mathrm{Cd}$ dan $\mathrm{Cr}$.

\subsection{Penentuan serapan $\mathrm{Cd}$ dan $\mathrm{Cr}$ di dalam sistem kontinu}

Inokulan fungi terdiri dari F0 (tanpa fungi $P$. chrysosporium), F1 (P.chrysosporium dosis 0 Gy) dan F2 (P. chrysosporium dosis optimal, $\quad \mathrm{X}$ $G y)$. Inokulan ini digunakan sebagai biosorben $\mathrm{Cd}(\mathrm{II})$ dan $\mathrm{Cr}(\mathrm{VI})$ pada reaktor kontinu dengan variasi waktu retensi (tinggal) terdiri dari $\mathrm{T} 1=3$ jam, $\mathrm{T} 2=6$ jam T3 = 9 jam dan T4 = 12 jam. Umpan terdiri dari larutan PDB, larutan logam $\mathrm{Cd}$ (II) 50 ppm dan larutan logam $\mathrm{Cr}(\mathrm{VI}) 50$ ppm dan disterilkan dengan autoclave pada $121^{\circ} \mathrm{C}$ selama 15 menit.

Umpan dialirkan dari bagian atas ke bawah reaktor melalui biosorben dengan variasi waktu retensi. Biosorpsi $\mathrm{Cd}(\mathrm{II})$ dan $\mathrm{Cr}(\mathrm{VI})$ dilakukan dalam reaktor kontinu selama 12 jam. Selanjutnya, effluent didestruksi untuk analisis serapan $\mathrm{Cd}$ dan $\mathrm{Cr}$ dengan AAS (Atomic Absorption Spectro-photometer). Variabel pengamatan terdiri dari $\mathrm{pH}$ efluent, viabilitas fungi, bahan organik, kadar air, serapan Cd dan Cr. Skema reaktor kontinu ditunjukkan pada Gambar 1.

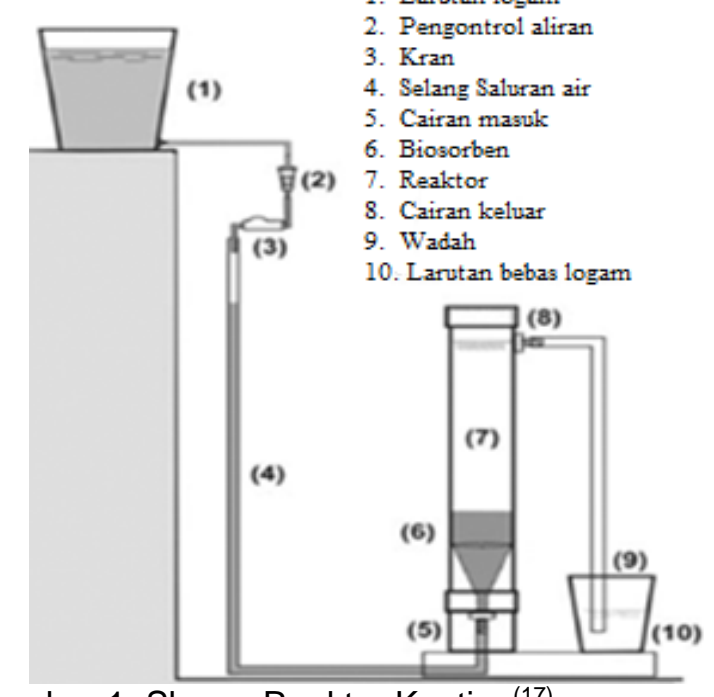

Gambar 1. Skema Reaktor Kontinu(17)

\subsection{Evaluasi Hari ke $\mathbf{0}$ dan $\mathbf{5}$}

\section{Penentuan $\mathrm{pH}^{(18)}$}

Penentuan $\mathrm{pH}$ sampel padat dan cair dengan $\mathrm{pH}$ meter digital. Sampel padat $5 \mathrm{~g}$ pada erlenmeyer $100 \mathrm{~mL}$ kemudian ditambahkan 25 $\mathrm{mL}$ aquades dan dikocok dengan shaker pada 100 rpm selama 30 menit. Supernatan dan endapan di-sentrifuse pada 5000 rpm, kemudian supernatan ditampung dalam gelas piala dan dilakukan pengukuran $\mathrm{pH}$.

\section{Penentuan viabilitas fungi ${ }^{(19)}$}

Viabilitas fungi ditentukan dengan metode Total Plate Count (TPC). Kultur fungi $1 \mathrm{~mL}$ ditambahkan $9 \mathrm{~mL}$ air fisiologis steril (0,85\% $\mathrm{NaCl})$ untuk memperoleh suspensi sampel. Suspensi diencerkan sampai $10^{7}$ menggunakan air fisiologis dan dituangkan ke atas lapisan PDA, diinkubasi pada suhu $30^{\circ} \mathrm{C}$. Penghitungan total fungi dilakukan pada inkubasi hari ke-3.

\section{Penentuan serapan $\mathrm{Cd}$ dan $\mathrm{Cr}^{(20)}$}

Setelah biosorpsi selama 12 jam, efluent didekstruksi dengan campuran asam nitrat dan asam perklorat (3:1). Hasil destruksi dimasukan ke dalam labu ukur dan ditepatkan menjadi 10 $\mathrm{mL}$ dengan akuades. Konsentrasi $\mathrm{Cd}$ dan $\mathrm{Cr}$ dalam filtrat dianalisis dengan Atomic Absorption Spectrophotometer (AAS) dengan menggunakan rumus seperti berikut :

$$
\begin{aligned}
\mathrm{q}_{\mathrm{e}}(\mathrm{mg} / \mathrm{g}) & =\frac{(\mathrm{Co}-\mathrm{Ct}) \times \mathrm{W}}{\mathrm{w}} \ldots \ldots \ldots \ldots \ldots(1) \\
\varepsilon(\%) & =\frac{\mathrm{Co}_{0}-\mathrm{Ct}}{\mathrm{Co}_{0}} \times 100 \% \ldots \ldots \ldots \ldots(2) \\
\text { Keterangan }: & \\
\varepsilon & =\text { efisiensi penyerapan }(\%) \\
\mathrm{C}_{0} & =\text { konsentrasi awal logam }(\mathrm{mg} / \mathrm{L}) \\
\mathrm{C}_{\mathrm{t}} & =\text { konsentrasi akhir logam }(\mathrm{mg} / \mathrm{L})
\end{aligned}
$$


$\mathrm{q}_{\mathrm{e}}=$ penyerapan ion logam $(\mathrm{mg} / \mathrm{g})$

$\mathrm{V}=$ volume larutan logam $(\mathrm{L})$

$\mathrm{W}=$ berat sampel $(\mathrm{g})$

\subsection{Analisis Data}

Data hasil penelitian dianalisis menggunakan analysis of variance (ANOVA) pada SPSS versi 20.0 dengan batas kepercayaan sebesar 95\% $(\alpha=0,05)$ dan dilanjutkan dengan uji Duncan. Penelitian menggunakan metode Rancangan Acak Lengkap (RAL) dengan 2 faktor dan 2 ulangan, faktor pertama yaitu FO (tanpa fungi P.chrysosporium), F1 (fungi P.chrysosporium 0 Gy), dan F2 (fungi P.chrysosporium X Gy) dan faktor kedua terdiri dari waktu retensi (tinggal) medium cair dalam biosorben (inokulan fungi) yang terdiri dari $\mathrm{T} 1=3 \mathrm{jam}, \mathrm{T} 2=6 \mathrm{jam}, \mathrm{T} 3=9$ jam dan $\mathrm{T} 4=12 \mathrm{jam}$.

\section{HASIL DAN PEMBAHASAN}

\subsection{Optimasi Dosis Radiasi}

Dosis radiasi optimum ditentukan melalui uji serapan ion logam berat $\mathrm{Cd}(\mathrm{II})$ dan $\mathrm{Cr}(\mathrm{VI})$ oleh $P$. chrysosporium dalam medium cair dengan dosis yang berbeda-beda yaitu 0, 250, 500, 750, dan 1000 Gy dapat dilihat pada Gambar 2. Gambar 2 menunjukkan bahwa dosis radiasi optimum pada 750 Gy dengan serapan ion Cd(II) sebesar 12,20 $\mathrm{mg} / \mathrm{g}$ dan serapan ion $\mathrm{Cr}(\mathrm{VI}) 8,73 \mathrm{mg} / \mathrm{g}$ dengan bobot biomassa $1,78 \mathrm{mg} / \mathrm{mL}$. Serapan $\mathrm{Cd}$ dan $\mathrm{Cr}$ turun pada dosis 250 Gy, kemudian naik pada dosis 500 Gy dan mencapai maksimum pada dosis 750 Gy dan turun kembali pada dosis 1000 Gy. Peningkatan dosis radiasi mengakibatkan penurunan viabilitas fungi. Hal ini tampak pada dosis 800 Gy dan 1000 Gy, di mana fungi tidak dapat memperbaiki kerusakan yang terjadi pada sel sehingga aktivitas enzim menurun ${ }^{(21)}$.

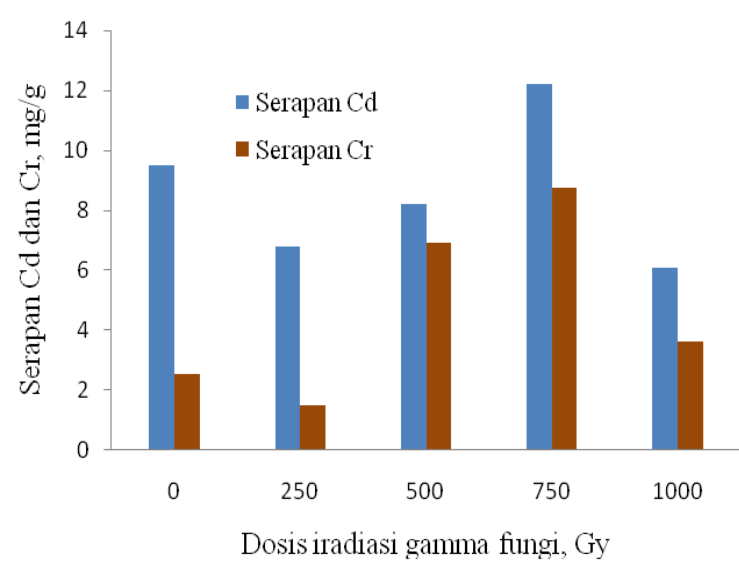

Gambar 2. Grafik hubungan dosis radiasi dengan serapan logam berat

Hasil uji statistik memperlihatkan beda nyata $(p<0,05)$ sehingga fungi yang optimal digunakan untuk proses biosorpsi logam $\mathrm{Cd}$ dan $\mathrm{Cr}$ adalah $P$. chrysosporium dengan dosis 750 Gy. Dosis yang diberikan merupakan dosis yang dapat ditoleransi, dimana kerusakan sel masih dapat diperbaiki sehingga menstimulasi aktivitas enzim lignin peroksidase $(\mathrm{LiP})^{(21)}$. Peningkatan aktivitas enzim lignin peroksidase (LiP) terjadi pada dosis 750 Gy. Dosis ini menyebabkan sel fungi rusak namun mampu memperbaiki yakni dengan meningkatnya aktivitas enzim ${ }^{(15)}$.

Interaksi sinar gamma dengan suatu sel akan menghasilkan radikal bebas atau spesi oksigen reaktif diantaranya adalah radikal superoksida $\left(\mathrm{O}_{2}{ }^{-}\right)$, radikal hidroksil $\left(\mathrm{OH}^{\circ}\right)$, dan hidrogen peroksida $\left(\mathrm{H}_{2} \mathrm{O}_{2}\right)^{(22)}$. Radikal-radikal bebas ini dapat memicu terjadinya stres oksidatif. Stress ini menyebabkan sel mengembangkan mekanisme proteksi untuk melawan efek oksigen reaktif dengan menghasilkan enzim yang lebih banyak ${ }^{(11)}$. Mekanisme radiasi sinar gamma terhadap sel dapat dilihat pada Gambar 3.

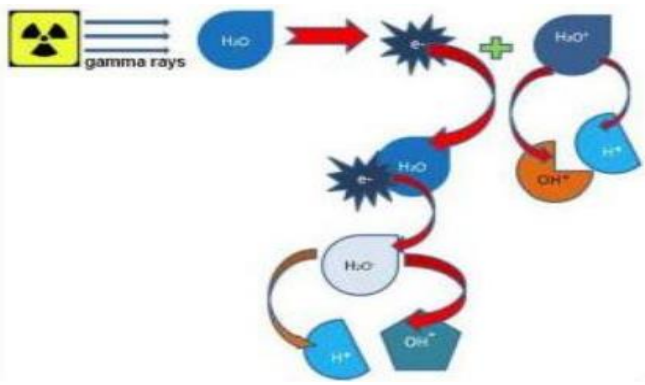

Gambar 3. Mekanisme radiasi gamma terhadap sel(23).

Peningkatan dosis radiasi gamma pada sel menyebabkan meningkatnya energi yang diterima oleh sel tersebut. Hal ini menyebabkan semakin banyak radikal bebas terbentuk akibat eksitasi elektron molekul air $\left(\mathrm{H}_{2} \mathrm{O}\right)$ dalam sel. Kemampuan regenerasi sel semakin rendah karena sel menerima dosis tinggi dalam waktu singkat yang menghambat pertumbuhan dan mematikan sel serta radiasi ini mampu menstimulasi fungi untuk memperbaiki bagian terinduksi dengan memproduksi enzim lebih banyak ${ }^{(24,25)}$.

\subsection{Viabilitas Inokulan P. chrysosporium dalam Carrier}

Kultur fungi $P$. chrysosporium digunakan membuat inokulan fungi dengan carrier organik padat. Carrier sebagai bahan tempat membawa sel hidup atau mikroba yang diinokulasikan di dalamnya dengan tujuan agar tetap hidup selama jangka waktu tertentu. Syarat carrier yang baik digunakan adalah $\mathrm{pH}$ netral $( \pm 6,47)$, mudah disteril dengan autoklaf atau radiasi sinar 
gamma, murah, tidak beracun, penyerapan dan kelembapan baik, dan tersedia dalam sumber daya yang cukup ${ }^{(26)}$.

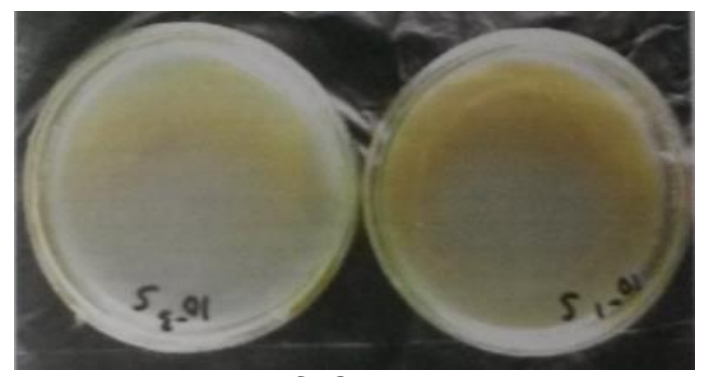

Gambar 4. Hasil TPC Carrier steril

Gambar 4 menunjukkan carrier yang steril dengan sinar Gamma Co-60 dosis 25 kGy, pada hari ke-0 tidak terdapat mikroba indigenous dan fungi yang menunjukkan bahwa iradiasi dosis 25 kGy mampu mensterilkan carrier ${ }^{(27)}$.

Kemampuan viabilitas fungi pada penyimpanan 14 hari dianalisis dengan menggunakan TPC (Total Plate Count), hasil yang diperoleh dilihat pada Tabel 1 .

Tabel 1. Hasil Uji TPC (Total Plate Count) Carrier

\begin{tabular}{clc}
\hline No & \multicolumn{1}{c}{ Sampel } & $\begin{array}{c}\text { TPC Log } 10 \\
\text { Propagul/gr }\end{array}$ \\
\hline 1 & IF0 (PC-0) & 7,42 \\
\hline & IF2 (PC- & 7,78 \\
\hline
\end{tabular}

Tabel 1 menunjukan bahwa viabilitas fungi IF2 (PC-750) yang diradiasi sinar gamma lebih besar dibandingkan dengan IF0 (PC-0) tanpa radiasi. Hasil ini menunjukkan bahwa perlakuan sinar gamma dosis rendah terhadap fungi dapat meningkatkan viabilitas karena radiasi dapat menstimulasi germinasi $i^{(27,28)}$.

Salah satu parameter pendukung dalam pertumbuhan $P$. chrysosporium di dalam carrier adalah bahan organik, dimana bahan organik carrier awal adalah $66.00 \%$, setelah inokulasi fungi PC-0 dan PC-750 di dalam carrier dan disimpan selama 14 hari kadar bahan organik carrier menurun menjadi $65,17 \%$ dan $65,15 \%$. Penurunan bahan organic disebabkan nutrisi pada bahan organik dirombak dan dimanfaatkan oleh fungi untuk pertumbuhannya ${ }^{(30)}$.

\subsection{Efisiensi serapan $\mathrm{Cd}$ dan $\mathrm{Cr}$ dalam Medium Cair}

Efisiensi serapan logam $\mathrm{Cd}$ dan $\mathrm{Cr}$ pada perlakuan: IF0 (carrier tanpa fungi), IF1 (carrier dengan fungi 0 Gy), dan IF2 (carrier dengan $P$. chrysosporium 750 Gy) ditentukan melalui media PDB (Potato Dextrose Broth) yang mengandung logam $\mathrm{Cd}$ dan $\mathrm{Cr} 50$ ppm pada $\mathrm{pH}$ 5,5. Biosorpsi dilakukan selama 3 hari menggunakan rotary shaker. Proses pengadukan bertujuan untuk menyeragamkan suhu dan konsentrasi nutrisi serta suspensi mikroba padat ${ }^{(31)}$. Serapan ion Cd dan $\mathrm{Cr}$ dianalisis dengan menggunakan Atomic Adsorption Spectrophotometer (AAS). Hasil serapan tampak pada Tabel 4.

Tabel 2. Efisiensi serapan ion $\mathrm{Cd}$ dan $\mathrm{Cr}$

\begin{tabular}{ccc}
\hline Sampel & $\begin{array}{c}\text { Serapan } \\
\text { Cd,\% }\end{array}$ & Serapan Cr, \% \\
\hline IF0 & 60,15 & 43,02 \\
\hline IF1 & 68,40 & 49,12 \\
\hline IF2 & 72,58 & 52,81 \\
\hline
\end{tabular}

Tabel 2 menunjukkan efisiensi serapan $\mathrm{Cd}$ dan $\mathrm{Cr}$ tertinggi pada IF2 dengan efisiensi serapan $\mathrm{Cd}$ sebesar $72,58 \%$ dan $\mathrm{Cr}$ sebesar $52,81 \%$, pada IF0 efisiensi serapan Cd sebesar $60,15 \%$ dan $\mathrm{Cr}$ sebesar $43,02 \%$ dan pada IF1 efisiensi serapan Cd sebesar 68,40\% dan $\mathrm{Cr}$ sebesar 49,12\%. Hasil Uji Statistik Duncan memperlihatkan beda nyata $(p<0,05)$ pada efisiensi serapan ion Cd dan Cr. Serapan IF2 lebih besar dibandingkan dengan IF0 dan IF1. Hal ini menunjukkan bahwa perlakuan sinar gamma terhadap fungi mampu menstimulasi peningkatan aktivitas enzim sehingga ketahanan fungi terhadap ion meningkat dan pengikatan logam menjadi besar ${ }^{(9,10)}$.

Fungi dengan carrier lebih tinggi serapan logamnya dibandingkan dengan yang hanya menggunakan carrier saja sebagai agen biosorbennya ${ }^{(12)}$. Setelah melalui proses inkubasi selama 3 hari semua nilai $\mathrm{pH}$ hasil akhir biosorbsi berada di bawah $\mathrm{pH}$ awal yaitu 5,5 . Hal ini terjadi karena proses biosorbsi menghasilkan asamasam organik seperti asam laktat dan piruvat yang lebih banyak ${ }^{(32)}$.

\subsection{Reduksi Logam Cd dan Cr pada Sistem Kontinu}

\section{Viabilitas Fungi Setelah Biosorpsi}

Viabilitas $P$. chrysosporium pada biosorpsi dengan sistem kontinu selama 12 jam dianalsis dengan menggunakan TPC (Total Plate Count).

Tabel 3. Hasil TPC Biosorben

\begin{tabular}{ccc}
\hline No & Sampel & TPC Log 10 Propagul/gr \\
\hline 1 & R1F1 & 8,60 \\
\hline 2 & R1F2 & 8,84 \\
\hline 3 & R2F1 & 8,47 \\
\hline 4 & R2F2 & 8,51 \\
\hline 5 & R3F1 & 8,55 \\
\hline 6 & R3F2 & 8,64 \\
\hline
\end{tabular}

Tabel 3 menunjukkan bahwa viabilitas fungi $P$. chrysosporium setelah proses biosorpsi 
setelah 12 jam rata-rata terbesar pada F2 (fungi dengan dosis $750 \mathrm{~Gy}$ ). Hal ini menunjukkan bahwa fungi $P$. chrysosporium resisten terhadap logam berat $\mathrm{Cd}$ dan $\mathrm{Cr}^{(33)}$.

\section{Nilai pH Setelah Proses Biosorpsi}

Parameter pertumbuhan $P$. chrysosporium dan proses biosorpsi adalah $\mathrm{pH}$, yang diukur pada jam ke 3, 6, 9, dan 12. Tabel 4 menunjukkan nilai $\mathrm{pH}$ tertinggi pada akhir biosorpsi pada reaktor kontinu selama 12 jam adalah pada R1F2 dan R2F2 yaitu 7,50 dan 7,43 dan serapan logamnya juga tertinggi dibandingkan R1F0, R1F1, R2F0, dan R2F1. Nilai $\mathrm{pH}$ tinggi dapat membantu mengurangi keberadaan logam berat dalam media, tetapi kapasitas serapan logam $\mathrm{Cd}(\mathrm{II})$ dan $\mathrm{Cr}(\mathrm{VI})$ pada R1F2 dan R2F2 lebih rendah dibandingkan kapasitas serapan logam $\mathrm{Cd}$ dan $\mathrm{Cr}$ pada R3F2 yaitu pada serapan logam Cd sebesar 5,956 $\mathrm{mg} / \mathrm{g}$ dan $\mathrm{Cr}$ sebesar $1,071 \mathrm{mg} / \mathrm{g}$ pada $\mathrm{pH}$ sebesar 6,48. Hal ini disebabkan karena aktivitas $P$. chrysosporium sebagai biosorben bekerja optimal pada $\mathrm{pH}$ 4-6. Enzim tidak dapat bekerja pada $\mathrm{pH}$ yang tidak sesuai karena akan mengalami denaturas ${ }^{(34,35)}$.

Tabel 4. Nilai pH setelah Biosorpsi

\begin{tabular}{ccccc} 
Perlakuan & $\begin{array}{c}3 \\
\text { Jam }\end{array}$ & $\begin{array}{c}6 \\
\text { Jam }\end{array}$ & $\begin{array}{c}9 \\
\text { Jam }\end{array}$ & $\begin{array}{c}12 \\
\text { Jam }\end{array}$ \\
\hline R1F0 & 6,13 & 6,21 & 6,54 & 6,65 \\
\hline R1F1 & 6,85 & 7,02 & 7,20 & 7,33 \\
\hline R1F2 & 6,78 & 7,06 & 7,39 & 7,50 \\
\hline R2F0 & 6,11 & 6,25 & 6,33 & 6,41 \\
\hline R2F1 & 6,78 & 7,00 & 7,15 & 7,30 \\
\hline R2F2 & 6,90 & 7,09 & 7,19 & 7,43 \\
\hline R3F0 & 5,92 & 5,69 & 5,65 & 5,54 \\
\hline R3F1 & 6,63 & 6,32 & 6,18 & 6,02 \\
\hline R3F2 & 6,77 & 6,66 & 6,55 & 6,48 \\
\hline
\end{tabular}

\section{Serapan Logam Cd dan $\mathrm{Cr}$}

Biosorpsi pada sistem kontinu dari F0 (tanpa fungi), F1 ( $P$. chrysosporium $0 \mathrm{~Gy}$ ) dan F2 ( $P$. chrysosporium $750 \mathrm{~Gy}$ ) dilakukan dengan tinggi reaktor $36 \mathrm{~cm}$ dan diameter $4,2 \mathrm{~cm}$. Variasi waktu tinggal terdiri dari $\mathrm{T} 1=3 \mathrm{jam}, \mathrm{T} 2=6 \mathrm{jam}$, $\mathrm{T} 3=9 \mathrm{jam}$ dan T4 = $12 \mathrm{jam}$. Laju alir reaktor kontinu dikalibrasi untuk menentukan debit aliran, dengan cara mengeser droplet dengan laju alir berbeda dan menampung air keluaran selama 1 jam lalu mengukur banyaknya air. Hasil kalibrasi didapati variasi kecepatan laju alir yaitu R1 dengan $32 \mathrm{~mL} / \mathrm{jam}, \mathrm{R} 2$ dengan $58 \mathrm{~mL} / \mathrm{jam}$ dan $\mathrm{R} 3$ dengan $204 \mathrm{~mL} / \mathrm{jam}$.

Kapasitas serapan ion $\mathrm{Cd}$ dan $\mathrm{Cr}$ setelah proses biosorpsi dalam reaktor kontinu, sampel diukur pada jam ke 12 dengan menggunakan
Atomic Adsorption Spectrophotometer (AAS). Hasil serapan dapat dilihat pada Gambar 5-7.

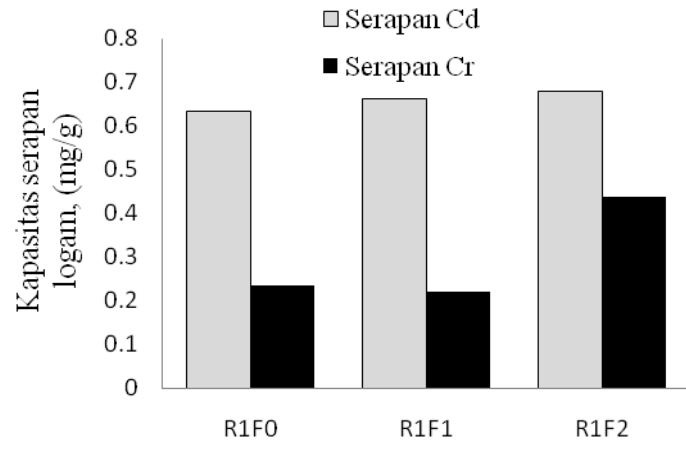

Gambar 5. Kapasitas serapan logam Cd dan $\mathrm{Cr}$ pada laju alir $32 \mathrm{~mL} / \mathrm{jam}$

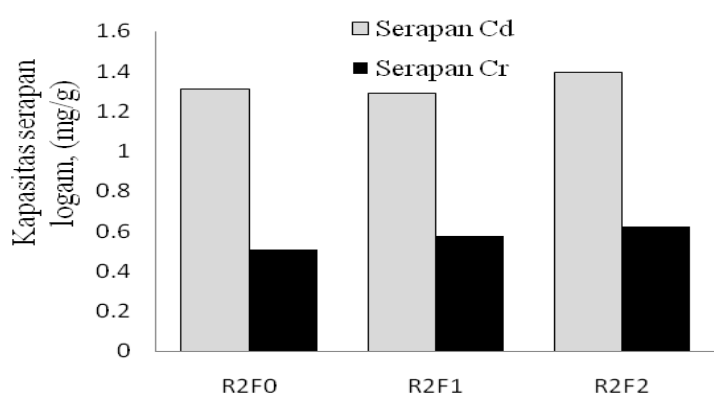

Gambar 6. Kapasitas serapan logam Cd dan Cr pada laju alir $58 \mathrm{~mL} / \mathrm{jam}$

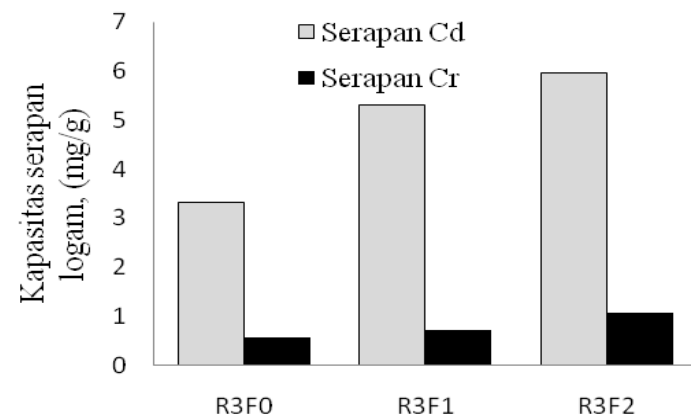

Gambar 7. Kapasitas serapan logam Cd dan Cr pada laju alir $204 \mathrm{~mL} / \mathrm{jam}$

Keterangan :

F0 $=$ Tanpa fungi $P$. chrysosporium

$\mathrm{F} 1=$ Fungi $P$. chrysosporium $0 \mathrm{~Gy}$

$\mathrm{R} 1=32 \mathrm{~mL} / \mathrm{jam}$

$\mathrm{R} 2=58 \mathrm{~mL} / \mathrm{jam}$

$\mathrm{R} 3=204 \mathrm{~mL} / \mathrm{jam}$

Gambar 5-7 menunjukkan bahwa serapan logam $\mathrm{Cd}$ dan $\mathrm{Cr}$ tertinggi adalah $\mathrm{F} 2$. Perlakuan R1F2 menghasilkan serapan logam Cd sebesar $0,68 \mathrm{mg} / \mathrm{g}$ dan $\mathrm{Cr}$ sebesar $0,437 \mathrm{mg} / \mathrm{g}$, Perlakuan R2F2 menghasilkan serapan logam Cd sebesar $1,394 \mathrm{mg} / \mathrm{g}$ dan $\mathrm{Cr}$ sebesar $0,623 \mathrm{mg} / \mathrm{g}$, dan perlakuan R3F2 menghasilkan serapan logam Cd sebesar $5,956 \mathrm{mg} / \mathrm{g}$ dan $\mathrm{Cr}$ sebesar 1,071 $\mathrm{mg} / \mathrm{g}$. Hasil Uji Statistik Duncan memperlihatkan 
beda nyata $(p<0,05)$ pada serapan logam $C d$ dan $\mathrm{Cr}$ dengan P.chrysosporium dosis $750 \mathrm{~Gy}$.

Adsorpsi ion logam merupakan adsorpsi fisik dimana gaya yang bekerja antar logam berat dari permukaan biosorben adalah gaya Van der Walls yang bersifat reversible karena proses penyerapan dapat dilepaskan kembali ke dalam pelarut, kecepatan pembentukan ikatannya cukup tinggi, sehingga regenerasi dapat dilakukan pada suhu rendah, dan semakin tinggi suhunya maka penyerapannya semakin kecil(36).

Biosorpsi logam $\mathrm{Cd}(\mathrm{II})$ dan $\mathrm{Cr}(\mathrm{VI})$ pada model ini adalah aliran dari atas ke bawah (Down Flow Fixed-Bed Column) menggunakan variasi kecepatan laju alir, dimana pada lapisan adsorben terjadi kontak secara langsung dengan larutan pada konsentrasi tertinggi sehingga menyerap larutan dengan konsentrasi yang lebih rendah. Gambar 7 menunjukkan kecepatan laju alir R3 $204 \mathrm{~mL} / j a m$ menghasilkan serapan logam yang lebih tinggi pada R3F2 yaitu serapan Cd sebesar $5,956 \mathrm{mg} / \mathrm{g}$ dan serapan $\mathrm{Cr}$ sebesar $1,071 \mathrm{mg} / \mathrm{g}$ dibandingkan dengan kecepatan laju alir R1 32 mL/jam dan laju alir R2 58 mL/jam. Hal ini terjadi karena peningkatan laju alir akan menambah tekanan dari aliran sehingga meningkatkan interaksi antara ion logam $\mathrm{Cd}$ dan $\mathrm{Cr}$ dengan biosorben sehingga mempengaruhi kapasitas adsorpsi.

Mekanisme penyerapan logam oleh $P$. chrysosporium adalah mekanisme ion exchange, ikatan kovalen, kelat, dan adsorpsi pada dinding sel. Dinding sel fungi tersusun dari beberapa polisakarida dan juga beberapa gugus fungsional yang berperan dalam mekanisme penyerapan ion $^{(37)}$. Gambaran mekanisme penyerapan ion oleh dinding sel dapat dilihat pada Gambar 8.

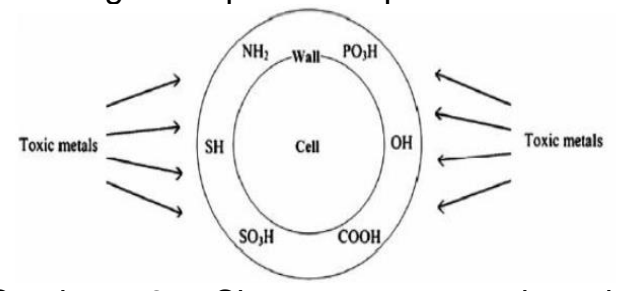

Gambar 8. Skema serapan ion logam terhadap gugus fungsional dinding sel biomassa( ${ }^{(38)}$.

Adsorpsi melalui pertukaran ion:

$$
\mathrm{S}-\mathrm{H} \alpha+\mathrm{M}^{2+} \longrightarrow \mathrm{S}-\mathrm{M}+\mathrm{H}^{+} \text {(Reaksi 1) }
$$

S-H mewakili situs adsorpsi permukaan adsorben, sedangkan $\mathrm{M}^{2+}$ adalah ion logam. konsentrasi kesetimbangan ion logam S-M adalah logam teradsorpsi pada biomassa, sedangkan $\alpha$ adalah koefisien protonik. Pada proses ini terjadi kompetisi antara ion $\mathrm{H}^{+}$dengan ion logam terhadap situs pertukaran kation. Mekanisme pertukaran kation dijelaskan pada reaksi berikut ${ }^{(39}$.)

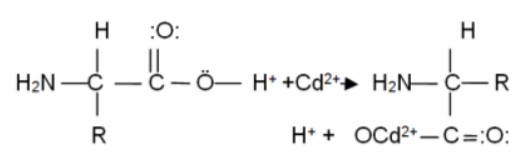

.... (Reaksi 2)

Mekanisme pertukaran ion ini terjadi pada saat gugus karboksilat $(\mathrm{COOH})$ mengalami deprotonasi akibat hadirnya ion hidroksida $\left(\mathrm{OH}^{-}\right)$, sehingga bermuatan negatif $\left(\mathrm{COO}^{-}\right)$yang sangat reaktif untuk berikatan dengan $\mathrm{Cd}^{2+(39)}$.

Ion $\mathrm{Cr}(\mathrm{VI})$ dalam medium $\mathrm{pH}$ 2-6 akan banyak terbentuk sebagai $\mathrm{CrO}_{4}^{2-}$ dan $\mathrm{Cr}_{2} \mathrm{O}_{7}^{2-}$. Gugus fungsi amina yang terdapat pada dinding sel fungi akan mengalami protonasi dan mengadsorpsi ion $\mathrm{Cr}^{(40)}$. Gugus fungsional pada dinding sel fungi yang paling banyak berperan dalam mekanisme penyerapan ion adalah gugus $-\mathrm{OH}$ dan $-\mathrm{NH}^{(41)}$. Adapun reaksi yang terjadi adalah (37):

$$
\begin{aligned}
& \mathrm{R}-\mathrm{NH}_{3}{ }^{+}+\mathrm{CrO}_{4}{ }^{2-} \rightarrow \mathrm{R}-\mathrm{NH}_{3}{ }^{+} \mathrm{CrO}_{4}{ }^{2-}(\text { Reaksi 3) } \\
& \mathrm{R}-\mathrm{NH}_{3}{ }^{+}+\mathrm{Cr}_{2} \mathrm{O}_{7}^{2-} \rightarrow \mathrm{R}-\mathrm{NH}_{3}{ }^{+} \mathrm{Cr}_{2} \mathrm{O}_{7}^{2-} \text { (Reaksi 4) }
\end{aligned}
$$

Selain mekanisme ion exchange, $P$. chrysosporium mengadsorpsi ion dengan mekanisme pembentukan kompleks dengan dinding sel yang mengandung polisakarida. Mekanisme pembentukan kelat dapat dilihat pada Gambar 9.

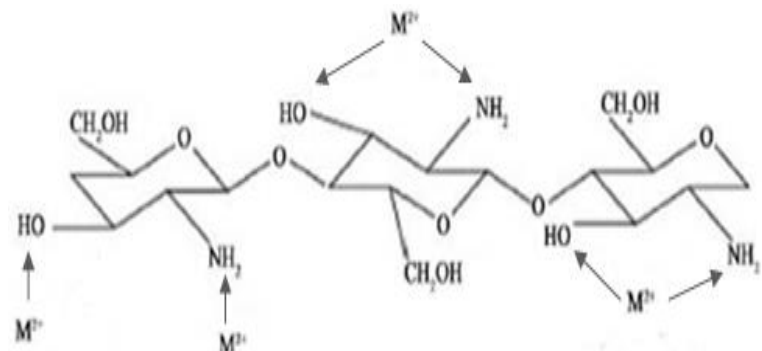

Gambar. 9 llustrasi pengikatan logam berat dengan dinding sel ${ }^{(42)}$.

Adsorben logam lain selain P. chrysosporium yaitu Carboxymethyl cellulose (CMC) yang terdapat dalam carrier. Penggunaan fungi dengan CMC sebagai biosorben berpengaruh terhadap penyerapan ion logam Cd(II) dan $\mathrm{Cr}(\mathrm{VI})$. Substrat CMC mengadsorpsi logam berat melalui mekanisme ion exchange. Struktur CMC memiliki gugus $\mathrm{Na}^{+}$dan gugus karbonil dan ketika bertemu dengan ion $\mathrm{Cd}$ dan $\mathrm{Cr}$, ion $\mathrm{Na}^{+}$ akan terlepas dari gugus karbonil( ${ }^{(43)}$. Mekanisme ion exchange antara CMC dengan logam berat Cd dapat dilihat gambar 10 . 


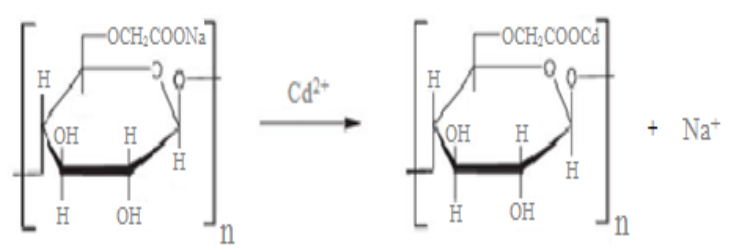

Gambar 10. Ion exchange antara CMC dengan ion $\mathrm{Cd}^{(44)}$.

\section{KESIMPULAN}

Reduksi logam berat Cd(II) dan $\mathrm{Cr}(\mathrm{IV})$ dalam sistem kontinu menggunakan fungi $P$. chrysosporium menghasilkan :

- Dosis optimum iradiasi sinar gamma pada fungi $P$. chrysosporium dalam menyerap logam $\mathrm{Cd}$ dan $\mathrm{Cr}$ adalah dosis radiasi 750 Gy.

- Serapan logam $\mathrm{Cd}$ dan $\mathrm{Cr}$ yang tertinggi dalam sistem kontinu setelah jam ke 12 adalah pada R3F2 dengan kecepatan laju alir 204 mL/jam menghasilkan serapan Cd sebesar 5,956 mg/g dan serapan $\mathrm{Cr}$ sebesar $1,071 \mathrm{mg} / \mathrm{g}$.

\section{DAFTAR PUSTAKA}

1. Iqbal, M., Edyvean, R. G. J. (2010). Alginate Coated Loofa Sponge Discs For The Removal of Cadmium from Aqueous Solutions. Biotechnol. Lett, Vol. 26 : 165169.

2. Slamet. (2012). Pengolahan Limbah Organik (Fenol) dan Logam Berat $\left(\mathrm{Cr}^{6+}\right)$ Secara Simultan dengan Fotokatalis $\mathrm{TiO}_{2}, \mathrm{ZnO}-\mathrm{TiO}_{2}$, dan $\mathrm{CdS}_{-} \mathrm{TiO}_{2}$, Universitas Indonesia. Jakarta. Makara, Teknologi. Vol. 9 (2) : 6671.

3. Ramos, R.L. (2010). "Adsorption of Cadmium (II) from Aqueous Solution onto Activated Carbon" Journal of Hazardous Material Vol. $173:$ 236-242.

4. Junior, L.M.B., E.P. Silvia, dan A.K.C. Lobato. (2003). Biosorption of Cadmium using the fungus Aspergillus niger.Braz.J.Chems. Eng. Vol. 20 (3) : 1-15.

5. Mohamad, E. (2012). Fitoremediasi Logam Berat Cd Pada Tanah Dengan Menggunakan Bayam Duri (Amaranthus spinosus L). Laporan Penelitian Pengembangan Iptek Dana PNBP Tahun Anggaran 2012 : Universitas Negeri Gorontalo; 13-28.

6. Veignie E, Rafin C, Woisel P, Cazier F. (2004). Preliminary evidence of the role of hydrogen peroxide in the degradation of benzo[a]pyrene by a non-white rot fungus Fusarium solani. Environ Pollut Vol.129 (1) : 1- 4.
7. Levin L.,A., Wiebke Z. , Guillermo F. M. , Valerie A. G., Michael D.T., Kevin M. B., Chris M., Joris M.G., Anthony E. R., (2003). Spatial heterogeneity of macrofauna at northern California methane seeps: influence of sulfide concentration and fluid flow, Mar Ecol Prog Ser. Vol. 265 : 123 139.

8. Sumit, Pal., and Vimala.Y. (2012). Comparative Study On Bioremediation Of Chromium In Fortified Solutions By Viable, Biosorbent And Immobilised Cells Of Phanerochaete chrysosporium- MTCC787, Intern.Journ.of Microbiology Research, Vol. 4 (6) : $240-248$

9. Afify, E.M.R., Mohamed, A.A.E., Ghada, M.I dan Bassam, W.K. (2013). Stimulating of Biodegradation of Oxamyl Pesticide by Low Dose Gamma Irradiated Fungi. J Plant Pathol Microb. Vol.4 : 9 - 13.

10. Shatele, M.S,. (2009). Effect of Gamma Irradiation on Fungal Growth and Associated Pathogens. Research Journal of Enviromental Toxicology. Vol. 3(2) : 94-100.

11. Sreedhar, M., Chaturvedi, A., Aparna, M., Kumar, P.D., Singhai, R.K and Babu, V. (2013). Influence of $\gamma$-radiation Stress on Scavenging Enzyme Activity and Cell Ultra Structure in Groundnut (Arachis hypogaea L.). Applied Science Resource. Vol. 2 (4) : 35-44.

12. Mulyana, N., Tri, R.D.L, Thamzil, L., dan Anita, R. (2015). Delignifikasi Substrat Kayu Jati Putih Dengan Fungi Phenerochaete Chrysosporium Untuk Meningkatkan Serapan $\mathrm{Pb}$ dan Cd Di Dalam Medium Cair. Prosiding Seminar Nasional Sains dan Teknologi Nuklir. 447 - 454.

13. Malihe A., Habibollah Y. , Nader B., Ali Akbar Z. L.,Farshid G., Ali D., Mazyar S.,. (2008), Application of response surface methodology for optimization of lead biosorption in an aqueous solution by Aspergillus niger, Journal of Hazardous Materials, Vol.154 : 694-702.

14. Aksu Z. (2003). Biosorption of Chromium (VI) lonts by Mowital B30 H Resin Immobilized Activated Sludge in a Packed Bed: Prediction of Breakthrough Curves. Process Biochem. Vol. 38 (2) : 175-186.

15. Priyo, W., Untung, S., Harsoyo, Aris, M., dan Dwi, W. (2005). Pengaruh Pemaparan Sinar Gamma Isotop Cobalt-60 dosis 0,25-1 kgy Terhadap Daya Antagonistik Trichoderma harzianum pada Fusarium oxysporum. Berk.Penel.Hayati,Vol. 10 : 143-151. 
16. Alka,T., Tulika, D., dan Bajpaib. (2008). Removal of Toxic As ( $\mathrm{V}$ ) lons by Adsorption onto Alginate and Carboxymethyl Cellulose Beads. Journal of the Chinese Chemical Society, Vol. 55 : 952-96.

17. Paramsothy. (2012). Optimizing Hydrolysis/ Acidogenesis Anaerobic Reactor With The Application of Microbial Reaction Kinetic. University of Peradeniya. Tropical Agricultural Research Vol. 16 : 327-338.

18. Association of Official Analytical Chemist (AOAC). (2000). Official Method of Analysis. Vol. 4 : 5-15.

19. Saraswati, R.E., Husen dan Simanungkalit. (2007). Metode Analisis Biologi Tanah, Balai Besar Penelitian dan Pengembangan Sumber daya Lahan Pertanian.Yogyakarta, ISBN: 978-602-8039-055.Vol.x : 10-18.

20. Tamer, A., Sibel, T. (2006). Biosorption characteristics of Aspergillus flavus biomass for removal of $\mathrm{Pb}$ (II) and $\mathrm{Cu}(\mathrm{II})$ ions from an aqueous solution. Bioresource Technology, Vol. 97 : 1780-1787.

21. Gunam, I.B.W., Buda, K., dan Guna, I.M.Y.S. (2010). Pengaruh Perlakuan Delignifikasi Dengan Larutan $\mathrm{NaOH}$ dan Konsentrasi Substrat Jerami Padi Terhadap Produksi Enzim Selulase dari Aspergillus niger NRRL Ali, 264. Jurnal Biologi XIV. Vol. $1: 55-61$.

22. Salter, L., dan Hewitt, C. N. (1992). Ozonehydrocarbon in plants. Photochemistry, Vol. 31 (4) : 4045-4050.

23. Aquino, S. (2012). Gamma Radiation. Intech Publisher ISBN 978-953-51-0316-5.171179.

24. Borzuei, A., Kafi, M., Khazaei, Naseriyan, B., dan Majdabadi. (2010). Effect of gamma irradiation on germination and physiological aspect of wheat (Triticum aestivum L.) seedlings. Pak. J. Bot. Vol. 42 (4) : 22812290.

25. Lydia, A., Sjarief, S.H., Sutarmi, A dan Sudrajad, D. (2002). Pengaruh Kapang Iradiasi untuk Produksi Glukosa dari Tepung Sagu. Majalah BATAN, $27: 25-34$.

26. Gupta, R., Beg, Q.K, dan Lorenz, P. (2007). Bacterial Alkaline Proteases: Molecular Approaches and Industrial Applications. Appl. Microbiol And Biotechnol. Vol. 59 (1) : 15-32.

27. Tri Retno D.L, Nana Mulyana dan Dadang S,. (2012), Pembuatan Bahan Pembawa Berbasis Vermikompos untuk Inokulan Bakteri Rhizosfer Peningkat Pertumbuhan
Tanaman", Pros.Pertemuan dan Presentasi IImiah Penelitian Dasar IImu Pengetahuan dan Tekn. Nuklir,Pusat Tekn. Akselerator dan Proses Bahan. ISSN 0216-3126 : 201207.

28. Tri, R.D.L.,Mulyana, N.,., Nurhasni dan Hasanah, U. (2016). Pengaruh Radiasi Gamma terhadap Kemampuan Degradasi Lignin Phanerochaete Chrysosporium dan Ganoderma lucidum, Jurnal Sains dan Teknologi Nuklir Indonesia Vol. 17 (1) : 2136.

29. Paillot, R., Robinson, C., Steward, K., Wright, N., Jourdan, T., Butcher, N., Heather, Z. \& Waller, A. S. (2010). Contribution of each of four superantigens to Streptococcus equi -induced mitogenicity, gamma interferon synthesis, and immunity. Infect Immun. Vol. 78 : 1728-1739.

30. Nelson dan Suparjo. (2011). Penentuan Lama Fermentasi Kulit Buah Kakao dengan Phanerochaete Chrysosporium: Evaluasi Kualitas Nutrisi Secara Kimiawi. Laboratorium Makanan Ternak Fakultas Peternakan Universitas Jambi. AGRINAK, Vol. 1 (1) : 1-10.

31. Siswati, Nana, D., Tenti, I., dan Meliya, R. (2015). Biosorpsi logam berat mercuri $(\mathrm{Hg})$ menggunakan biomassa Phanerochaete Chrysosporium. Jurnal IImiah Teknik Lingkungan. Vol. 1, (2) : 67-72.

32. Pacheco, Josue S., Monserrath S., dan Maria G.A.U. (2015). Ability of Phanerochaete Chrysosporium and Tramates versicolor to remove $\mathrm{Zn}^{2+}, \mathrm{Cr}^{3+}$, $\mathrm{Pb}^{2+}$ metal ions. Terra Lationamericana, Vol. 33 (3) : 190-198.

33. Joshi, P.K, Swarup, A, Maheshwari, S, Kumar, R, Singh, N. (2011). Bioremediation of heavy metals in liquid media through fungi isolated from contaminated sources. Indian J Microbiol, Vol. 51 : 482-487.

34. Huang, C.P. dan M. H. Wu. (2012). Chromium Removal by Carbon Adsorption. Jurnal Water Pollution Control Fedeartion, Vol.47(10) : 2437-2443.

35. Safaria, S., N. Idiawati dan T.A. Zaharah. (2013). Efektivitas Campur Enzim Selulse dari Aspergillus niger dan Trichoderma reesei Dalam Menghidrolisis Substrat Sabut Kelapa. JKK, Vol. 2 (1) : 46-51.

36. Mufrodi, Z. Widiastuti, N. Dan Kardika, R. C. (2008). Adsorpsi Zat Warna Tekstil dengan Menggunakan Abu Terbang (Fly Ash) untuk Variasi Massa Adsorben dan Suhu Operasi. Prosiding Seminar Nasional Teknoindustri, 
Universitas Ahmad Dahlan, Yogyakarta:9093.

37. Chen, G., Wen J.Z., Guang M, dan Jin ,H. (2011). Surface-modified Phanerochaete Chrysosporium as a biosorbent for $\mathrm{Cr}(\mathrm{VI})$ contaminated wastewater. Journal of Hazardous Material. Vol. 186 : 2138-2143.

38. Javanbakht, V., Alavi S.A dan Zilouci, H. (2014). Mechanism Of Heavy Metal Removal Using Microorganisms As Biosorbent. Water Science and Technology.Vol. 69 :1775 - 1787.

39. Tangio, J.S. (2013). Adsorpsi Logam Timbal $(\mathrm{Pb})$ dengan Menggunakan Biomassa Enceng Gondok (Eichhorniacrassipes). Jurnal Entropi. Vol. 3 (1) : 501-506.

40. Gurgel, V, Melo, J.C.P, Lena, J.C. (2009). Adsorption of chromium (VI) ion from aqueous solution by succinylated mercerized cellulose functionalized with quartenary ammonium groups. Bioresour. Techol. Vol. $100: 3214-3220$.
41. Xu, P, Guang M.Z, dan Lian, H. (2012). Adsorption of $\mathrm{Pb}(\mathrm{II})$ by iron oxide nanoparticel immobilized Phanerochaete Chrysosporium: Equilibrium, kinetic, thermodynamic and mechanisms analysis. Chemical Engineering Journal , Vol. 203 : 423-431.

42. Hebeish, Elnagar K.H., Helal, M.H., Ragab, M.S dan Shaaban, M.F. (2011). UV/O 3 Preirradiated Cotton Fabric-Containing Chitin for Effective Removal Heavy Metals. Materials Sciences and Apllications. Vol. 5 (10) : 698 - 707.

43. Wang, M., Ling, X., Jing, P., dan Maolin, Z. (2009). Adsorption And Desorption of $\operatorname{Sr}(I I)$ Ions In The Gels Based On Polysaccharide Derivates. Journal of Hazardous Material, Vol. $171: 820-826$.

44. Roosevelt D.S. Bezerra, Paulo R.S. Teixeira, dan Ana S.N.M. Teixeira. (2015). CelluloseFundamental Aspects and Current Trends. Intech, 93 -113. 